\section{Complications of regional blocks: what do we really know?}

David L. Brown MD
W

HEN seeking to understand better what we really know about complications associated with regional anesthesia it is important to make a clear distinction between the terms, complications and sideeffects. As example, some suggest that hypotension is the most common complication of spinal anesthesia. ${ }^{1}$ I believe it more accurate to characterize hypotension as a side-effect, not a complication. To me, a complication is associated with the continuum of time; that is, the complication has a measurable length of morbid effect, not the briefness associated with the common blood pressure decreases that are easily treated with ephedrine during a spinal anesthetic. With that background, there are complications associated with regional anesthesia, and yet the challenge of "really knowing" about them are their rarity, the lack of uniform training in the subspecialty of regional anesthesia, the increasing focus of using regional anesthetics for postoperative analgesia rather than intraoperative care, and the apparent easy linkage of these adverse events to the needles and drugs used in our regional anesthetics by those unfamiliar with their use. Finally, a problem in analyzing regional anesthetic complications is that, for many physicians, the "default mode" of anesthetic practice seems to be general anesthesia. It often appears for regional anesthesia to be widely accepted by these physicians it must be clearly safer, not simply as safe as general anesthesia. We will attempt to understand each of these issues impacting "what we really know" about regional anesthesia.

\section{Statistical problems of rare anesthetic complications}

Many equate anesthetic mortality, or other major morbidity as the ultimate in anesthetic complications. This severely limits our ability to understand complications better, since an anesthetic death or an episode of severe morbidity (e.g. cauda equina syndrome) are infrequent events, probably > $1: 100,000$ in ASA I/II patients undergoing non-body cavity surgery. ${ }^{2}$ A British report on mortality suggests that the overwhelming majority of perioperative deaths within 30 days of operation, i.e. $67 \%$, were due to underlying patient disease, with surgical and anesthetic causes being responsible for the remaining $30 \%$ and $2 \%$ of deaths, respectively. ${ }^{3}$ Prospectively studying the complications of anesthetic mortality or major morbidity in healthy patients will be frustrating due to the size and expense of the study. ${ }^{4}$ Thankfully, this dilemma is due to the remarkable safety of anesthesia. In spite of this relative safety, reports of cauda equina syndrome developing following spinal anesthesia do alter our practice of regional anesthesia. Often, the recommendation for a change in practice is based on in vitro studies that attempt to mimic the clinical situation. ${ }^{5}$ We only need to reflect on the clinical confusion arising out of the nineteenth-century chloroform commission studies to gain appreciation of how far away from clinical reality in vitro anesthetic experimentation can lead from truly understanding the clinical issue. $^{2}$

Another way of understanding the statistical problem of rare events can be highlighted by outlining a hypothetical clinical study, in which a comparison of two techniques of axillary nerve block and development of neuropathy are tested. If an assumption is made that the incidence of postoperative neuropathy is $1 \%$, and you want to find a technique that reduces this to $0.5 \%$, approximately 7,400 patients would need to be studied if the alpha ${ }^{\mathrm{a}}$ ( $P$ value) were set at 0.1 and the power ${ }^{b}$ at $80 \% .^{6}$ Additionally, development of an understanding of perioperative neuropathy risks requires not only study of neuropathy after regional anesthesia, but also after general anesthesia. This concept is important since, although there often seems to

\footnotetext{
${ }^{a}$ alpha is the risk of a false-positive result (Type I error), i.e. finding an experimental difference when no difference exists

b power equals l-beta (i.e. the probability of finding a statistically significant difference when a difference really exists): beta is the probability of making a false-negative error (type II error)
}

Department of Anesthesia, University of Iowa, 200 Hawkins Drive, Iowa City, Iowa, 52242-1079 USA 
be an etiological link between needles and neuropathy, the facts suggest neuropathy may be as, or even more, frequent following general anesthesia. ${ }^{7-9}$

\section{Incomplete training risks and regional anesthesia}

Complication rates linked to regional anesthesia practice are also impacted by the opportunity to learn regional anesthesia during residency training, and these opportunities vary widely. A lack of opportunity may lead to increased complications as trainees enter their initial practices if expectations between their regional anesthesia performance and experience diverge. For example, in one North American training program, residents performed only two subarachnoid blocks per year compared with another in which 234 spinals per yr were administered by residents. ${ }^{10}$ These 1980 data were restudied in 1990 and, although regional anesthesia use had increased in most training programs, it was due almost completely to an increase in postoperative epidural analgesia." ${ }^{11}$ The American Board of Anesthesiology has promulgated minimal training requirements in order for USA residency training programs to meet accreditation requirements for our specialty's ACGME Residency Review Committee. In spite of these minimal numbers there is evidence that "acceptable success" with neuraxial blocks takes approximately 40 of each spinal and epidural anesthetics, even when the experience is gained during a concentrated (six month) training interval. ${ }^{12}$ These relative low numbers of blocks needed to assure success must be balanced against the knowledge that a Swiss study suggests higher numbers of blocks are required to assure success. ${ }^{13}$ These investigators found that during the first year of residency training epidural anesthesia was the most difficult anesthetic procedure to learn, and they estimated 90 epidural anesthetics are needed during this interval to assure success. In another European investigation, French residents completing training reported experience with $44 \pm 3$ and $31 \pm 4$, upper and lower extremity blocks, respectively, in a survey designed to assess experience with peripheral nerve blocks. ${ }^{14}$ Both of these frequencies are likely below the number required to achieve success if the Swiss estimates are accurate. With these many studies as background, I believe the frequency and comprehensiveness of regional anesthesia training undoubtedly impact upon complication rates, and demand further study.

\section{The complete perioperative period and regional anes-} thesia

Expanding our focus of regional anesthetic complications from an exclusively intraoperative to a perioper- ative one may be the most important step in developing a more comprehensive understanding of regional anesthetic complications. Intraoperative anesthetic choice affects the postoperative course of our patients. ${ }^{15-18}$ The expansion of perioperative risk-benefit analysis to include the entire recovery period of patients may allow a more accurate balancing of complication frequency and clinical benefit, thus allowing patients to receive more comprehensive anesthetic and surgical care. For example, neurohumoral events associated with anesthetic and analgesic prescription (epidural regional analgesia), affect the coagulation system at a basic level. ${ }^{19,20}$ The Johns Hopkins group showed that epidural anesthesia and analgesia limit the increase in an inhibitor (PAI-1) of plasminogen activation found postoperatively in vascular surgery patients. Thus, risk analysis of regional anesthesia in vascular surgery patients needs to include the frequency of the complication of reoperation in the same riskbenefit equation as the remote rate of epidural hematoma development. ${ }^{21}$ Only when this more complete approach to complication analysis is taken will we begin to "really know" about balancing regional anesthetic complications and benefits.

\section{Clinical regional anesthetic complications}

In spite of these perspectives balancing benefits and complications of regional anesthetics, complications do occur. The most commonly cited important complications associated with regional anesthetics are neurotoxicity following blocks, local anesthetic systemic toxic reactions, and neuraxial bleeding after spinals or epidurals. Although complete coverage of each of these risks is beyond the scope of this manuscript there are a number of issues that deserve highlighting.

It is clear that, with increasing concentration of local anesthetic, any of the local anesthetics can be neurotoxic. ${ }^{22}$ Nevertheless, currently, the neurotoxicity issue is focused primarily on whether lidocaine used for spinal anesthesia has previously unrecognized unique injury patterns associated with its clinical use. There have been many in vitro reports highlighting the potential of lidocaine for neurotoxicity when delivered in high concentration in experimental settings. ${ }^{23}$ There have also been many reports describing what, I believe, is often an imprecisely defined clinical syndrome - transient radicular irritation (TRI) - or alternatively, transient neurologic symptoms (TNS). ${ }^{24}$ These reports must be balanced with the knowledge that over 50 million lidocaine spinal anesthetics have been administered over the years with apparently minimal adverse outcome. At present, to this clinician, there are still indications for using 
lidocaine as a spinal anesthetic although, arbitrarily, I seek to keep the dose below 60 to $75 \mathrm{mg}$, inject with as much speed as practical, and often use 22 -gauge conetipped spinal needles, rather than smaller gauge needles. These adjustments in practice are based on a developing, but untested clinical hypothesis that development of TRI results from the use of small-gauge, cone-tipped spinal needles that have lateral openings, coupled with a slow injection of lidocaine. ${ }^{25}$

Local anesthetic systemic toxicity appears, to me, to be greatly feared by anesthesiologists and professional research careers have been built on better understanding local anesthetic systemic toxic effects. This local anesthetic systemic toxicity arises both from too much drug delivered in the correct location, or from the proper amount of drug delivered unintentionally into a patient's circulation. Both of these factors end in the common pathway of high blood concentrations of local anesthetic perfusing the brain. Likely, high blood levels of local anesthetic perfusing the amygdala initiate the seizure, which then propagates to involve the cerebrum. By far the most common cause of this form of toxicity is unintentional injection of local anesthetic directly into the circulation. ${ }^{26}$ Although there is considerable fear of cardiovascular depression associated with local anesthetic systemic toxicity, clinical data suggest that, in most circumstances, patients have catecholamine release during the seizure which leads to increases in heart rate and blood pressure. Benzodiazepines are specific and effective in controlling the sub-cortical seizures. These drugs lower the excitability of the limbic structures and may be helpful in minimizing systemic toxicity related to high blood levels of local anesthetic related to use of a large mass of local anesthetic. Investigators suggest the frequency of seizures secondary to the clinical use of local anesthetics in experienced hands is 0.1 to $0.33 \% .{ }^{27}$ There is a predictable pattern of peak serum levels depending on the site of the block, and the seemingly constant focus on recommended maximum amount of local anesthetic by those less familiar with regional anesthesia. This may be particularly irrelevant since most systemic toxic reactions are from direct intravascular injection of local anesthetic rather than from rapid systemic uptake from block sites. ${ }^{28,29}$ What does seem clear is that immediate treatment of a systemic toxic reaction is important to minimize risk to our patients.

Neuraxial bleeding has achieved considerable interest over the last few years in the USA due to the increasing use of both neuraxial blocks for anesthesia and analgesia and low molecular weight heparins for perioperative thromboembolism prophylaxis. Clinicians in the USA are using LMWH at a higher dose than their
European colleagues and, in addition, often at more frequent intervals. ${ }^{30}$ This has resulted in development of consensus statements for use of neuraxial anesthetics with $\mathrm{LMWH}$, which were created at an international consensus conference in Chicago, IL on May 2-3,1998. The manuscripts from this conference appeared as a supplement to Regional Anesthesia and Pain Medicine in 1998. In general, the primary recommendation of the consensus development is to communicate clearly within an institution the suggested practice parameters when using both neuraxial anesthesia or analgesia when patients are also receiving LMWH. When this clinical circumstance does arise, it is recommended to avoid neuraxial puncture for 10-12 hr after the last LMWH dose and, perhaps, even up to $24 \mathrm{hr}$ if a higher dose of LMWH (e.g. $>1$ mg. $\mathrm{kg}^{-1}$ enoxaparin on a twice daily schedule) is administered. Another, unexpected observation from the consensus meeting was recognition that withdrawal of neuraxial catheters from patients receiving LMWH appear to carry the same level of risk for hematoma development as neuraxial puncture. Thus, the same timing issues should be considered in the catheter withdrawal setting.

\section{What we need for the future to minimize regional anesthesia complications}

I believe our patients will be best served when there is further blurring of anesthetic prescription between general and regional anesthesia. When that occurs, it will likely indicate a more comprehensive understanding exists about anesthetic complications. Further, improved imaging techniques of peripheral nerve sites will both decrease reliance on neuraxial blocks and improve the success rate of peripheral nerve blocks. Both of these developments will move us toward less frequent signifcant complications with regional anesthesia. Finally, we need to continue our enthusiastic use and investigation of regional anesthesia so that our future patients benefit from its unrivaled perioperative analgesic properties.

\section{References}

1 Moore $D C$, Bridenbaugh $L D$, Bagdi $P A$, Bridenbaugh $P O$, Stander $H$. The present status of spinal (subarachnoid) and epidural (peridural) block: a comparison of the two techniques. Anesth Analg 1968; 47: 40-9.

2 Brown DL. Anesthesia risk: a historical perspective. In: Brown DL (Ed.). Risk and Outcome in Anesthesia, 2nd ed. Philadelphia: J.B. Lippincott, 1992: 1-35.

3 Spence AA. The lessons of CEPOD (Editorial). $\mathrm{Br} J$ Anaesth 1988; 60: 753.

4 Forrest JB, Rebder K, Goldsmith CH, et al. Multicenter study of general anesthesia. I. Design and patient demography. Anesthesiology 1990; 72: 252-61. 
5 Thompson GE. Continuous spinal anesthesia: an ASRA perspective. Reg Anesth 1963; 18(6S): 387.

6 Pocock SJ. Clinical Trials. London: John Wiley and Sons, 1983: 123-35.

7 Kroll DA, Caplan RA, Posner K, Ward RJ, Cheney F. Nerve injury associated with anesthesia. Anesthesiology 1990; 73: 202-7.

8 Dawson DM, Krarup C. Perioperative nerve lesions. Arch Neurol 1989; 46: 1355-60.

9 Alvine FG, Schurrer ME. Postoperative ulnar-nerve palsy: are there predisposing factors? J Bone Joint Surg 1987; 69-A: 255.

10 Bridenbaugh $L D$. Are anesthesia resident programs failing regional anesthesia. Reg Anesth 1982; 7: 26-8.

11 Kopacz DJ, Bridenbaugh LD. Are residency programs failing regional anesthesia? The past, the present, the future. Reg Anesth 1993; 18: 84-7.

12 Kopacz DJ, Neal JM. Learning regional anesthesia techniques: how many is enough? Reg Anesth 1994; 19(S): 37.

13 Konrad C, Schupfer G, Wietlisbach $M$, Gerber $H$. Learning manual skills in anesthesiology: is there a recommended number of cases for anesthetic procedures. Anesth AnaIg 1998; 86: 635-9.

14 Bouaziz $H$, Mercier FJ, Narchi P, Poupard M, Auroy $\Upsilon$, Benbamou D. Survey of regional anesthetic practice among French residents at time of certification. Reg Anesth 1997; 22: 218-22.

15 Yeager MP, Glass DD, Neff $R K$, et al. Epidural anesthesia and analgesia in high-risk surgical patients. Anesthesiology 1987; 66: 729-36.

16 Tperskoy M, Cozacov C, Ayache M, Bradley EL, Kissin I. Postoperative pain after inguinal herniorraphy with different types of anesthesia. Anesth Analg 1990; 70 : 29-35.

17 Tuman KJ, McCartby RJ, March RJ, et al. Effects of epidural anesthesia and analgesia on coagulation and outcome after major vascular surgery Anesth Analg 1991; 73: 696-704.

18 Merry AF, Ramage MC, Whitlock RML, et al. Firsttime coronary artery bypass grafting: the anaesthetist as a risk factor. Br J Anaesth 1992; 68: 6-12.

19 Christopherson R, Beattie C, Frank SM, et al. Perioperative morbidity in patients randomized to epidural or general anesthesia for lower extremity vascular surgery. Anesthesiology 1993; 79: 422-34.

20 Rosenfeld $B A$, Beattie $C$, Christopherson $R$, et al. The effects of different anesthetic regimens on fibrinolysis and the development of postoperative arterial thrombosis. Anesthesiology 1993; 79: 435-43.

21 Horlocker TT, Wedel DJ. Anticoagulants and antiplatelet therapy and neuraxis blockade. Anesth Clin North Am 1992; 10: 1.
22 Ready RB, Plumer MH, Hascke RH, et al. Neurotoxicity of intrathecal local anesthetics in rabbits. Anesthesiology 1985; 63: 364-70.

23 Sakura $S$, Hashimoto $K$, Bollen $A W$, Ciriales $R$, Drasner $K$. Intrathecal catheterization in the rat: improved technique for morphologic analysis of drug-induced injury. Anesthesiology 1996; 85: 1184-9.

24 Pollock J, Neal J, Stephenson C, et al. Prospective study of the incidence of transient radicular irritation in patients undergoing spinal anesthesia. Anesthesiology 1996; 84: 1361-7.

25 Pollock J. Spinal lidocaine: what is TRI? American Society of Anesthesiologists Meeting, ASRA Breakfast Panel, San Diego, California, October 1997.

26 Scott DB. "Maximum recommended doses" of local anaesthetic drugs (Editorial). Br J Anaesth 1989; 63: 373-4.

27 Garfield JM, Gugino L. Effects of local anesthetics on electrical activity of the brain. In: Strichartz GR (Ed.). Local Anesthetics. Handbook of Experimental Pharmacology, Vol 81. Berlin, Springer-Verlag, 1987: 254.

28 Codino BG, Vassallo HG. Local Anesthetics. Orlando, Florida: Grune \& Stratton, 1976.

29 Brown DL, Ransom DM, Hall JA, Leicht CH, Schroeder $D R$, Offord KP. Regional anesthesia and local anesthetic-induced systemic toxicity: seizure frequency and accompanying cardiovascular changes. Anesth Analg 1995; 81 : 321-8.

30 VandePol C. Enoxaparin and epidural analgesia (Letter). Anesthesiology 1995; 85: 433-4. 


\section{Complications du bloc régional : qu'en savons- nous réellement ?}

David L. Brown MD

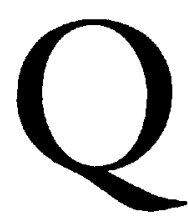

UAND nous cherchons à mieux comprendre ce que nous savons réellement des complications associées à l'anesthésie régionale, il est important de faire une distinction claire entre les termes complications et effets secondaires. On parle, par exemple, de l'hypotension comme de la complication la plus fréquente en rachianesthésie. ${ }^{1}$ Nous croyons qu'il est plus juste de parler d'effet secondaire dans ce cas. Selon nous, une complication est associée à une période de temps ; c'est-à-dire qu'elle a un effet morbide de longueur mesurable, non la brièveté des baisses courantes de tension artérielle qui sont facilement traitées à l'éphédrine pendant la rachianesthésie. Cela étant dit, il y a des complications associées à l'anesthésie régionale, et pour réussir à «savoir réellement» ce qu'elles sont, il faut être au courant de leur rareté, du manque d'uniformité dans la formation des sous-spécialités de l'anesthésie régionale, de l'habitude croissante d'utiliser les anesthésiques régionaux pour l'analgésie postopératoire plutôt que pour le traitement peropératoire et de la liaison apparente et facile qui est faite entre ces incidents défavorables et les aiguilles et les médicaments utilisés pour les anesthésies régionales par des gens non familiarisés avec leur usage. Finalement, le problème de l'analyse des complications de l'anesthésie régionale vient du fait que, pour de nombreux médecins, le mode «par défaut» de la pratique anesthésique semble être l'anesthésie générale. Il arrive souvent que l'anesthésie régionale, pour être largement acceptée par ces médecins, doive être manifestement plus sûre et non simplement aussi sûre que l'anesthésie générale. Nous tenterons de préciser chacun de ces aspects qui englobent «ce que nous savons réellement» de l'anesthésie régionale.

\section{Problèmes statistiques des complications anesthésiques exceptionnelles}

Pour beaucoup, la mortalité liée à l'anesthésique, ou d'autre morbidité majeure, représente la complication anesthésique ultime. Cette équation limite considérablement notre habileté à comprendre mieux les complications, puisque le décès lié à l'anesthésie ou un épisode de morbidité sévère (comme le syndrome de la queue de cheval) sont des événements très rares, probablement $>1: 100000$ chez les patients ASA I/II subissant une chirurgie non intrathoracique ou non intra-abdominale. ${ }^{2}$ Un rapport britannique sur la mortalité avance que la très grande majorité $(67 \%)$ des décès périopératoires qui surviennent moins de 30 jours après l'opération étaient causés par la maladie du patient, les causes chirurgicales et anesthésiques étant responsables des autres $30 \%$ et $2 \%$ de décès, respectivement. ${ }^{3}$ Des études prospectives portant sur les complications anesthésiques qui peuvent provoquer la mort ou une morbidité importante chez des patients en santé seraient très insatisfaisantes, car ces études sont longues et coûteuses. ${ }^{4}$ Heureusement, cet inconvénient tient au fait de la remarquable sécurité de l'anesthésie. Malgré cette relative sécurité, les cas de syndrome de la queue de cheval rapportés à la suite de rachianesthésie influencent certainement notre pratique de l'anesthésie régionale. Souvent, les changements de pratique recommandés sont basés sur des études in vitro qui tentent d'imiter la situation clinique. ${ }^{5}$ Nous n'avons qu'à réfléchir à la confusion clinique engendrée par les études de la commission sur le chloroforme au dix-neuvième siècle pour mieux comprendre jusqu'où l'expérimentation anesthésique in vitro peut être loin de la réalité et que cette situation nous empêche d'en découvrir la véritable portée clinique. ${ }^{2}$

Une autre façon de comprendre le problème statistique des incidents rares peut être mise en lumière en traçant les grandes lignes d'une étude clinique hypothétique dans laquelle on teste par comparaison deux techniques de bloc nerveux axillaire et le développement de neuropathie. Si nous supposons que l'incidence de neuropathie postopératoire est de 1 $\%$, et que nous voulons trouver une technique qui la réduise à $0,5 \%$, il faudra étudier environ 7400 patients si alpha (valeur de $P$ ) est fixé à 0,1 et la puissance $^{b}$ à $80 \%{ }^{6}$ De plus, les risques de neuropathie périopératoire seront micux compris par une étude portant non seulement sur la période postopératoire de l'anesthésie régionale, mais aussi de l'anesthésie générale. Ce concept est important puisque, même s'il semble y avoir souvent un lien étiologique entre les 
aiguilles et la neuropathie, les faits laissent plutôt croire que la neuropathie peut être aussi, sinon plus, fréquente après l'anesthésie générale. ${ }^{7-9}$

\section{Risques de l'entrainement incomplet et anesthésie régionale}

Les taux de complications liées à la pratique de l'anesthésie régionale dépendent aussi de l'apprentissage de l'anesthésie régionale pendant la résidence, ce qui varie largement. Un entraînement déficient peut conduire à des complications accrues au moment où les stagiaires abordent leur première pratique si leur expérience de l'anesthésie régionale ne correspond pas à leurs attentes de performance. Par exemple, dans un programme nord-américain, les résidents réalisent seulement deux blocs sous-arachnoïdiens par année en comparaison d'un autre programme qui comporte 234 rachianesthésies par année, administrées par les résidents. ${ }^{10}$ Ces données de 1980 ont été réétudiées en 1990 et, bien que le recours à l'anesthésie régionale avait augmenté dans la plupart des programmes d'entraînement, c'était lié presque exclusivement à l'analgésie péridurale postopératoire. ${ }^{11}$ L'American Board of Anesthesiology (Conseil américain d'anesthésiologie) a promulgué les exigences minimales d'entrainement dans le but de permettre aux programmes d'entrainement américains de répondre aux exigences de l'accréditation du ACGME Residency Review Committee (comité sans équivalent canadien) de notre spécialité. Malgré cela, certaines indications laissent croire que la «réussite acceptable» des blocs neuraxiaux demande à peu près 40 anesthésies de chaque modalité, rachidienne et péridurale, même pendant un entraînement intensif (six mois) ${ }^{12}$ Ce nombre relativement bas doit être placé en perspective, sachant qu'une étude suisse suggère qu'un nombre plus élevé de blocs soit nécessaire pour assurer le succès. ${ }^{13}$ Les chercheurs ont trouvé que pendant la première année de résidence, l'anesthésie péridurale est la méthode la plus difficile à apprendre, et ils croient qu'il faut 90 interventions pendant six mois pour garantir le succès. Dans une autre recherche européenne, des résidents français en formation ont rapporté une expérience de

\footnotetext{
- alpha représente le risque de résultat faussement positif (Type d'erreur I), c.-̀̀-d. trouver une différence expérimentale alors qu'aucune différence n'existe

${ }^{\mathrm{b}}$ puissance équivaut à 1-bêta (c.-à-d. la probabilité de trouver une différence statistique significative lorsqu'une différence existe réellement): bêta est la probabilité de faire l'erreur d'un faux négatif (erreur de type II)
}

$44 \pm 3$ et $31 \pm 4$ blocs pour les membres supérieurs et inférieurs respectivement, lors d'une enquête conçue pour évaluer leur expérience du blocage des nerfs périphériques. ${ }^{14}$ C'est sans doute insuffisants pour atteindre le succès si les estimations suisses sont exactes. Avec toutes ces études en arrière-plan, nous croyons que la fréquence d'utilisation de l'anesthésie régionale et l'exhaustivité de son entraînement ont un impact certain sur le taux de complications, et demandent d'autres études.

\section{La période périopératoire complète et l'anesthésie régionale}

En ne mettant plus l'accent exclusivement sur l'aspect peropératoire des complications de l'anesthésie régionale, mais plutôt sur leur aspect périopératoire, plus étendu, nous franchissons une des plus importantes étapes dans le développement d'une meilleure compréhension des complications anesthésiques régionales. Le choix anesthésique peropératoire a un effet sur l'évolution postopératoire de nos patients. ${ }^{15}$ ${ }^{18}$ Étendre l'analyse du rapport bénéfice/risque périopératoire en y incluant le temps d'une récupération complète des patients peut permettre un équilibre plus précis entre la fréquence des complications et des bénéfices cliniques, et donner alors la chance aux patients de recevoir de meilleurs soins anesthésiques et chirurgicaux. Par exemple, des événements neurohumoraux associés à la prescription anesthésique et analgésique (analgésie péridurale régionale), ont un effet sur le système de base de la coagulation. ${ }^{19,20}$ Le groupe de Johns Hopkins a montré que l'anesthésie et l'analgésie péridurales limitent l'augmentation dans un inhibiteur (IAP-1) de l'activation du plasminogène trouvé après l'opération chez les patients en chirurgie vasculaire. Ainsi, l'analyse du risque de l'anesthésie régionale chez ces patients exige l'inclusion de la fréquence d'une nouvelle opération, comme complication possible, dans la même équation risque-bénéfice que le taux infime de développement d'un hématome péridural. ${ }^{21} \mathrm{Ce}$ n'est qu'au moment où nous adopterons cette méthode d'analyse plus complète des complications que nous commencerons à «savoir vraiment» ce qu'est l'équilibre entre les complications et les bénéfices de l'anesthésie régionale.

\section{Complications cliniques de l'anesthésie régionale}

En dépit de ces perspectives d'équilibre entre bénéfices et complications des anesthésiques régionaux, les complications existent bel et bien. Les complications les plus importantes citées comme étant associées aux anesthésiques régionaux sont la neurotoxicité qui suit les blocs, les réactions toxiques généralisées à 
l'anesthésique local et les saignements périmédullaires après des injections rachidiennes ou péridurales. Même si la couverture complète de ces risques dépasse la portée du présent texte, il y a un certain nombre de questions qui méritent d'être élucidées.

Il est clair qu'avec l'accroissement de la concentration d'anesthésique local, tous les anesthésiques locaux peuvent être neurotoxiques. ${ }^{22}$ Néanmoins, à propos de la neurotoxicité, on cherche surtout à découvrir présentement s'il existe des caractéristiques lésionnelles particulières, méconnues auparavant, qui seraient associées à l'utilisation clinique de la lidocaine pour la rachianesthésie. Il y a eu beaucoup de recherches in vitro mettant en lumière le potentiel de toxicité de la lidocaïne quand elle était administrée en forte concentration dans les situations expérimentales. ${ }^{23}$ Il y a eu aussi de nombreux articles décrivant ce qui, croyons-nous, est souvent un syndrome clinique mal défini - l'irritation radiculaire transitoire (IRT) - ou encore symptômes neurologiques transitoires (SNT) ${ }^{24}$ Ces données doivent être mises en parallèle avec le fait que plus de $\mathbf{5 0}$ millions de rachianesthésies ont été réalisées au fil des ans avec des effets secondaires apparents minimaux. Nous croyons qu'il y a toujours des indications pour l'usage de la lidocaïne en tant qu'anesthésique rachidien quoique, arbitrairement, nous tentions de conserver la dose sous les 60 à $75 \mathrm{mg}$, injectée aussi vite que possible, et avec des aiguilles rachidiennes à pointe conique de calibre 22 plutôt que des aiguilles de plus petit calibre. Ces ajustements de pratique sont basés sur une hypothèse qui a cours sans avoir été testée en clinique et qui veut que le développement de l'IRT résulte de l'usage d'aiguilles de petit calibre, dont la pointe est conique et qui ont des ouvertures latérales, couplé à une injection lente de lidocaïne. ${ }^{25}$

La toxicité anesthésique généralisée nous semble très redoutée par les anesthésiologistes dont certains ont bâti leur carrière de chercheur professionnel en voulant mieux connaître les effets toxiques généralisés des anesthésiques locaux. Cette toxicité provient à la fois de l'emploi d'une trop grande quantité administrée au bon site ou de la bonne quantité de médicament administrée involontairement dans la circulation du patient. Ces deux événements provoquent la même conséquence, soit une forte concentration sanguine d'anesthésique local qui perfuse le cerveau. Il est probable que les hauts niveaux sanguins d'anesthésique local qui perfuse l'amygdale cérébelleuse provoquent une crise qui s'étend ensuite et envahit le cerveau. L'injection involontaire d'anesthésique local directement dans la circulation constitue, de loin, la cause la plus commune de cette forme de toxicite. ${ }^{26}$ Bien qu'il y ait une grande crainte de dépression cardiovasculaire associée à la toxi- cité généralisée de l'anesthésique local, les données cliniques rappellent que, dans la majorité des cas, la libération de catécholamine s'est produite pendant la crise, ce qui a conduit à un accroissement de la fréquence cardiaque et de la tension artérielle. Les benzodiazépines ont une action spécifique et efficace de contrôle des crises sous-corticales. Ces médicaments réduisent l'excitabilité des structures limbiques et peuvent aider à diminuer la toxicité générale reliée aux niveaux sanguins élevés d'anesthésique local liés à l'usage d'une grande quantité de cet anesthésique. Les chercheurs mentionnent que la fréquence de crises secondaires à l'usage clinique d'anesthésiques locaux par des mains expertes est de 0,1 à $0,33 \%{ }^{27}$ Il existe un modèle prévisible de niveau sérique maximal basé sur le site du bloc et, semble-t-il, sur une tendance constante à utiliser la dose maximale recommandée d'anesthésique local par ceux qui sont moins familiarisés avec l'anesthésie régionale. C'est particulièrement hors de propos, puisque la plupart des réactions toxiques généralisées sont liées à l'injection intravasculaire directe d'anesthésique local plutôt qu'à l'assimilation rapide à partir du site du bloc. ${ }^{28,29} \mathrm{Ce}$ qui semble clair, par ailleurs, c'est l'importance d'un traitement immédiat des réactions toxiques générales afin de réduire les risques chez nos patients.

L'intérêt pour les saignements périmédullaires s'est accru au cours des dernières années aux É-U à cause de l'emploi plus fréquent de blocages périmédullaires pour l'anesthésie et l'analgésie, et d'héparine de bas poids moléculaire (HBPM) pour les mesures prophylactiques périopératoires de la thromboembolie. Les cliniciens américains utilisent de plus grandes doses d'HBPM que leurs confrères européens et, de plus, souvent à des intervalles plus fréquents. ${ }^{30}$ Cette situation a conduit à l'élaboration de directives communes sur l'usage d'anesthésiques neuraxiaux associés à l'HBPM, lors d'une conférence internationale à Chicago, en Illinois, les 2 et 3 mai 1998. Les textes de cette conférence sont publiés comme supplément à la revue Regional Anesthesia and Pain Medicine en 1998. De façon générale, la principale recommandation du consensus est de faire connaître clairement à l'intérieur de l'institution les paramètres de pratique suggérés quand on utilise l'anesthésie ou l'analgésie neuraxiale et que les patients reçoivent aussi de l'HBPM. Dans une telle situation clinique, on recommande d'éviter la ponction neuraxiale pendant 10-12 $h$ après la dernière dose d'HBPM et, peut-être même jusqu'à $24 \mathrm{~h}$ après si une plus forte dose d'HBPM (par ex. $>1 \mathrm{mg} \cdot \mathrm{kg}^{-1} \mathrm{~d}^{\mathrm{e}}$ 'noxaparine selon une dose biquotidienne) est administrée. Une autre observation, inattendue, de la rencontre consensuelle a été de reconnaître que le retrait d'un cathéter neuraxial chez 
des patients qui reçoivent de l'HBPM semble comporter le même risque d'apparition d'un hématome que la ponction neuraxiale. Par conséquent, le retrait du cathéter devrait se faire selon un horaire semblable.

\section{Comment réduire à l'avenir les complications de}

l'anesthésie régionale

Nous croyons que nos patients seront mieux servis lorsque les différences entre la prescription anesthésique générale et régionale seront de plus en plus infimes. Quand cela se produira, on saura qu'il existe une meilleure compréhension des complications anesthésiques. En outre, l'amélioration des techniques d'imagerie des sites des nerfs périphériques va permettre de diminuer le recours aux blocs neuraxiaux et d'améliorer le taux de succès des blocs des nerfs périphériques. Ces deux événements vont réduire la fréquence de complications importantes reliées à l'anesthésie régionale. Finalement, nous devons continuer à nous intéresser à l'usage de l'anesthésie régionale et à la recherche sur le sujet de sorte que nos futurs patients puissent bénéficier de ses propriétés analgésiques périopératoires incontestées.

\section{Références}

(Voir page R12) 